Per Øystein Haavold

UiT Norges arktiske universitet

DOI: http://dx.doi.org/10.5617/adno.4797

\title{
I hvilken grad påvirker omvendt undervisning elevenes matematikkunnskap og oppfatninger om matematikk?
}

\section{Sammendrag}

De siste årene har omvendt undervisning, eller flipped classroom, vært mye omtalt i både norsk og utenlandsk skoledebatt. I en gjennomgang av relevant litteratur konkluderer Estes, Ingram og Liu (2014) at omvendt undervisning kan ha en positiv lceringseffekt. I denne studien ble et kvasieksperiment gjennomført på tre videregående skoler for å undersøke i hvilken grad omvendt undervisning påvirket lceringsutbyttet i matematikk, sammenlignet med tradisjonell undervisning. Det ble også undersøkt om omvendt undervisning kan påvirke elevers oppfatninger om matematikk. På én av de tre skolene var omvendt undervisning innført. Elevenes matematikkunnskap og oppfatninger om matematikk ble testet ved starten og slutten av et skoleår. Elevenes besvarelser ble deretter analysert for å se om det var statistiske forskjeller i endring av lcringsutbyttet og oppfatninger om matematikk mellom elever som hadde hatt omvendt undervisning og elever som hadde hatt tradisjonell undervisning. Analysene viste at elevene som fikk omvendt undervisning, hadde en større faglig fremgang enn elevene som fikk tradisjonell undervisning. Analysene viste også at elevene som fikk omvendt undervisning, endret sine oppfatninger om matematikk i større grad enn elever som fikk tradisjonell undervisning. Dette kan tyde på at omvendt undervisning er et tiltak som kan være med på å styrke elevenes læeringsutbytte i skolematematikk. Men i denne studien ble ikke selve undervisningen observert. Det betyr at også andre faktorer kan ha påvirket resultatene. For å undersøke omvendt undervisning i matematikk fremover, vil det derfor vœre nødvendig å undersøke selve undervisningen ncermere.

Nøkkelord: omvendt undervisning, lceringsutbytte, kvasieksperiment, oppfatninger 


\title{
To what extent does flipped classroom affect students' mathematical knowledge and conceptions of mathematics?
}

\begin{abstract}
Flipped classroom is a popular trend in education. In a review of relevant literature, Estes, Ingram and Liu (2014), conclude that flipped classroom can have a positive effect on students' learning. In this study, a quasi-experiment was carried out in three upper secondary schools to investigate to what extent flipped classroom can affect students' learning outcome in mathematics, compared to traditional teaching. The study also investigated whether flipped classroom can affect students' conceptions of mathematics. Flipped classroom was introduced in one of the three schools. Students' mathematical knowledge and conceptions of mathematics were tested at the start and finish of one school year. The students' responses were then analyzed to see if there were statistical differences in change of learning outcome between students in flipped classrooms and students in traditional classrooms. The analyses showed that students in flipped classrooms had a larger increase in mathematical knowledge and larger change of conceptions of mathematics than students in traditional classrooms. This indicates that flipped classroom can have a positive effect on students' learning outcomes, compared to traditional classrooms. However, the actual teaching was not observed. Other variables may therefore have had an effect on the results. Future investigations of flipped classroom in mathematics should therefore also focus on the teaching itself.
\end{abstract}

Keywords: flipped classroom, learning outcome, quasi-experiment, conceptions

\section{Innledning}

De siste årene har omvendt undervisning, eller flipped classroom, vært mye omtalt i både norsk og utenlandsk skoledebatt (Bishop \& Verleger, 2013). Omvendt undervisning betyr kort fortalt at deler av undervisningen, som regel teorigjennomgang, er tilgjengelig på film, som elevene ser hjemme. Dermed frigjøres tid på skolen til andre læringsaktiviteter. Denne undervisningsformen snur opp ned på tradisjonell undervisning, der teorigjennomgangen skjer på lærestedene, mens lekser og oppgaveløsing skjer utenfor organisert undervisning. I en litteraturgjennomgang av relevante studier konkluderte Bishop og Verleger (2013) med at i de fleste studiene av omvendt undervisning har forskere benyttet et én-gruppe-design for å undersøke elevers og studenters erfaringer med omvendt undervisning. Men ifølge forfatterne har det vært gjennomført få studier der læringsutbyttet av omvendt undervisning har blitt undersøkt systematisk; de anbefaler derfor at fremtidige studier også benytter seg av kvasieksperimentelle 
og eksperimentelle design med flere grupper, der læringsutbyttet granskes eksplisitt. I denne studien benyttes et kvasieksperimentelt design for å undersøke læringsutbyttet i matematikk av omvendt undervisning, sammenlignet med tradisjonell undervisning.

Norske elevers kunnskap i matematikk har fått mye oppmerksomhet de siste årene - særlig på grunn av resultater i internasjonale undersøkelser som PISA (Kjærnsli \& Jensen, 2016) og TIMSS (Bergem, Kaarstein \& Nilsen, 2016). Dette har resultert i en stor satsing på realfag og matematikk i Norge, som for eksempel regjeringens nye satsing «Tett på realfag» som ny strategi for realfag i barnehagen og grunnopplæringen (Kunnskapsdepartementet, 2016), og Ludvigsen-utvalgets rapport «Fremtidens skole» (NOU 2015:08). I begge rapportene konkluderes det med at fremtidens realfag og skole i større grad må sikte mot dybdelæring, med mer bruk av undersøkende læringsformer som i større grad aktiviserer elevene kognitivt. Dybdelæring medfører ifølge Ludvigsen-utvalget at elever knytter nye ideer og begreper til tidligere kunnskap og erfaringer. Ved å analysere, løse problemer og reflektere over egen læring kan elever organisere egen kunnskap i systemer som henger tett sammen, og dermed skape en bedre og mer varig forståelse innenfor et fagområde. I en gjennomgang av relevant litteratur konkluderer Estes, Ingram og Liu (2014) at omvendt undervisning kan legge til rette for dybdelæring. Ved å flytte grunnleggende teorigjennomgang til film som elevene ser hjemme, frigjøres tid i fellesundervisningen til læringsaktiviteter som kan legge til rette for dybdelæring, som problembasert og undersøkende undervisning.

Omvendt undervisning kan altså være med å legge til rette for en hensiktsmessig faglig aktivitet i matematikk i skolen. Men hva er hensiktsmessig aktivitet i skolematematikk? Schoenfeld (1992) belyser dette spørsmålet ved å vise til to ytterpunkter av oppfatninger om matematikk som fag. På den ene siden kan matematikk sies å være en samling av fakta, teknikker, algoritmer, teoremer osv. På den andre siden kan matematikk sies å være vitenskapen om mønstre, der vi først og fremst genererer og løser problemer, samt argumenterer og resonnerer. Frem til 1980-tallet var førstnevnte ytterpunkt mye utbredt, men i senere tid har brede kompetansemodeller som inkluderer begge ytterpunktene blitt dominerende. Kilpatrick, Swafford og Findell (2001) beskriver for eksempel matematisk kompetanse som fem sammensatte og sammenflettede komponenter: begrepsforståelse, beregning, anvendelse, resonnering, og engasjement. Andre, som for eksempel Niss og Jensen (2002) og TIMSS (Grønmo, Lindquist, Arora \& Mullis, 2013), har foreslått lignende flerdimensjonale og brede rammeverk for matematisk kompetanse. Dersom vi tar utgangspunkt i et bredt kompetansebegrep, bør skolematematikk inkludere både fakta, teknikker og algoritmer, samt problemløsing, argumentasjon og resonnering.

Trening og gjentakelse er nødvendig for at kunnskap og ferdigheter skal lagres i langtidsminnet (APA, 2015). Men den viktigste forutsetningen for at elever skal lære bestemte kompetanser i matematikk, er at de får en mulighet til det - 
opportunity to learn (Hiebert \& Grouws, 2007). For at elevene skal lære seg å «tenke matematisk», utvikle en god forståelse i og for faget og tilegne seg en bred kompetanse, må de møte læringssituasjoner og undervisning som legger til rette for det. I et forsøk på å beskrive hva som kjennetegner slik undervisning, har Schoenfeld og The Teaching for Robust Understanding Project (2016) utviklet et forskningsbasert rammeverk, Teaching for Robust Understanding (TRU). Ifølge TRU er kvaliteten på undervisningen avhengig av fem dimensjoner: det matematikkfaglige innholdet, passende kognitive utfordringer, at alle elever kan delta og engasjere seg, at elever får mulighet til å utvikle og bruke egne ideer, og formativ vurdering.

Ved å flytte noe av teorigjennomgangen ut av klasserommet, frigjøres det tid til å fokusere på noe av det som vektlegges i blant annet TRU. Omvendt undervisning er en måte å organisere undervisningen på som kan være med på å legge til rette for at elever skal tilegne seg en bred kompetanse i matematikk. I denne studien undersøker jeg derfor følgende problemstilling:

a) I hvilken grad påvirker omvendt undervisning i matematikk elevenes matematikkunnskap?

I tillegg til faglig læringsutbytte er det også interessant å se nærmere på om omvendt undervisning påvirker elevenes oppfatninger av matematikk som fag. Mange elever oppfatter matematikk som en samling fakta man skal lære seg, men som ikke har noen betydning for deres eget liv. Vi vet at elevers oppfatninger av matematikk påvirker hvordan de lærer matematikk. Hvis en elev oppfatter matematikk som en samling av fakta og regler som skal pugges, så vil det i stor grad være det eleven fokuserer på i læringssituasjoner (Philipp, 2007). I omvendt undervisning vil det kunne legges til rette for dybdelæring og problemløsing i matematikk, som igjen kan påvirke elevenes oppfatning om matematikk. Jeg vil derfor også undersøke følgende problemstilling:

b) I hvilken grad påvirker omvendt undervisning i matematikk elevenes oppfatninger om matematikk?

I forskningslitteraturen finner man en rekke forskjellige definisjoner av oppfatninger, og relaterte begreper som forestillinger (beliefs), affekt, kunnskap osv. I et forsøk på å syntetisere relevant litteratur, definerte Philipp (2007, s. 259) oppfatninger som «a general notion or mental structure encompassing beliefs, meanings, concepts, propositions, rules, mental images, and preferences». Det betyr at oppfatninger inkluderer både forestillinger og kunnskap om verden rundt oss og vår rolle i den. Forskjellen mellom forestillinger og kunnskap ligger i at kunnskap er forestillinger som vi er overbevist om er sanne (Philipp, 2007).

Ifølge Beswick (2012) kan oppfatninger om matematikk i skolen deles inn i tre underkategorier: 1) oppfatninger om matematikk; 2) oppfatninger om læring av matematikk; og 3) oppfatninger om undervisning av matematikk. Grovt sett 
kan disse tre underkategoriene deles inn i det Thompson (1992) kaller begrepsorientering (conceptual orientation) og beregningsorientering (calculational orientation). Begrepsorientering er nært knyttet til oppfatninger om matematikk som vitenskapen om mønstre, der problemløsing, forståelse av begreper og matematisk tenkning er i fokus i undervisning og læring. Beregningsorientering er derimot nærmere knyttet til oppfatninger om matematikk som bestående av fakta og teknikker, der fokus er på å identifisere og benytte prosedyrer for å løse problemer og komme frem til rett svar. Det er her viktig å påpeke at ingen av de to orienteringene nødvendigvis er korrekt. De er også overlappende og ikke gjensidig utelukkende, og det er mulig å holde tilsynelatende motstridende oppfatninger. Men dette skillet gir et utgangspunkt for å identifisere og analysere individers oppfatninger om matematikk (Thompson, 1992).

\section{Omvendt undervisning}

Omvendt undervisning (flipped classroom) blir definert av Lage, Platt og Treglia (2000) slik: «Inverting the classroom means that events that have traditionally taken place inside the classroom now take place outside the classroom and vice versa» (s. 32). Men for å trekke et skille mellom en nyere forståelse av omvendt undervisning og tradisjonelle leselekser, mener Bishop og Verleger (2013) at omvendt undervisning i tillegg må inkludere bruk av film utenfor klasseromsundervisningen. Andre forskere har definert omvendt undervisning på lignende måter, der de har fastslått at tradisjonelle teoriforedrag flyttes ut av fellesundervisningen og erstattes av engasjerende samarbeidslæring, dybdelæring og underveisvurdering (se f.eks. Abeysekera \& Dawson, 2015). Det betyr for eksempel at elevene først ser en kort filmsnutt utenfor fellesundervisningen, der et matematisk begrep, ide, eller teknikk introduseres. Deretter benyttes fellesundervisningen til mer undersøkende og elevaktive undervisningsformer som kan legge til rette for samarbeidslæring, dybdelæring og underveisvurdering. Her ligger begrunnelsen ifølge Bishop og Verleger (2013) i en motvilje mot å bruke klasseromsundervisning til tradisjonelle foredrag der lærer forklarer og elever lytter. Jeg vil derfor i denne artikkelen benytte begrepene fellesundervisning og klasseromsundervisning om den delen av undervisningen som foregår i felleskap med lærere og elever til stede i samme rom.

Ifølge Krumsvik og Jones (2016) finner man at de fleste studier innenfor området viser til konstruktivistiske og sosiokulturelle læringsteorier, som bygger på henholdsvis Piagets (1967) og Vygotskys (1978) arbeider. Innen det sosiokulturelle læringsperspektivet ses læring på som noe som konstrueres i samhandling med andre gjennom språk og artefakter, mens innen konstruktivistiske læringsteorier vektlegges det at individer aktivt konstruerer kunnskap gjennom en meningssøkende prosess der nye inntrykk forstås i lys av eksisterende kunnskap. I tillegg til en rent læringsteoretisk begrunnelse der samhandling og 
elevsentrerte aktiviteter vektlegges for å legge til rette for dybdelæring, er også den teknologiske utviklingen en viktig årsak til fremveksten av omvendt undervisning. Bruk av film og online lekser har blitt mer vanlig i undervisning, og enkelte studier har dokumentert en positiv effekt av dem (Bishop \& Verleger, 2013).

Men til tross for fremveksten av digitale verktøy i undervisning, og at omvendt undervisning er en mye omtalt trend innen utdanning, finnes det lite systematisk evaluering av omvendt undervisning som er underlagt forskningsmessige konvensjoner (Krumsvik \& Jones, 2016). I en litteraturgjennomgang på området fant Bishop og Verleger (2013) 24 studier som var relatert til omvendt undervisning. Til tross for variasjoner i forskningsdesign i studiene, var det flere trekk som gikk igjen. De fleste elever og studenter var positive til omvendt undervisning, og de så som regel videoene utenfor klasseromsundervisningen. Sistnevnte funn er særlig interessant, da Sappington, Kinsey og Munsayac, (2002) skriver at studenter sjelden leser pensum før forelesninger. Videoforelesninger kan dermed bidra til å stimulere til økt læringsaktivitet utenfor fellesundervisningen. Estes mfl. (2014) kom frem til lignende konklusjoner i sin litteraturgjennomgang av studier knyttet til omvendt undervisning:

The literature review reinforces the sense that the flipping technique is useful when seeking to optimize class time, support the development of higher-order thinking skills, and enhance teacher-student and student peer-to-peer interactions. (s. 7)

Men av de 24 studiene som Bishop og Verleger (2013) så på, var det kun to som hadde et rendyrket omvendt undervisnings-design. Et rendyrket omvendt undervisnings-design måtte inkludere to ting: a) elevsentrerte læringsaktiviteter i fellesundervisning, og b) undervisningsfilmer utenfor fellesundervisningen. I den første studien fant Moravec, Williams, Aguilar-Roca og O’Dowd (2010) at studenter som fulgte omvendt undervisning i et biologikurs, presterte $21 \%$ bedre enn andre studenter på eksamensoppgaver. I den andre studien av Day og Folay (2006) konkluderte forfatterne at studenter som fulgte omvendt undervisning i et datainteraksjonskurs, presterte bedre enn studenter som fulgte tradisjonell undervisning på hjemmearbeid, prosjekter og tester. I en nyere studie fra Norge rapporterte Krumsvik og Jones (2016) om lignende funn i en casestudie som rettet seg mot omvendt undervisning i naturfag i en påbyggingsklasse. Forfatterne konkluderer etter åtte ukers feltarbeid og før- og etter-test at det er en positiv sammenheng mellom lærerens omvendte undervisning og elevenes faglige læringsutbytte. Det kan dermed se ut til at omvendt undervisning kan ha en positiv effekt på elevers læringsutbytte, men det empiriske grunnlaget er p.t. svakt.

Selv om noen studier indikerer økt læringsutbytte for elever som følger omvendt undervisning, har andre studier rapportert om negative effekter. I flere studier kommer det frem at studenter eller elever oppfatter omvendt undervisning som forstyrrende og mindre tilfredsstillende enn tradisjonelle undervisningsformer (Wasserman, Quint, Norris \& Carr, 2017). Ferreri og O’Connor 
(2013) fant for eksempel at negative vurderinger av et farmakalogiemne økte fra 33 til $50 \%$ etter at underviserne la om til omvendt undervisning. I en annen studie konkluderte Strayer (2012) at studenter i et statistikkemne med omvendt undervisning oppfattet undervisningen som mindre læringsfokusert enn studenter som tok det samme statistikkemnet med tradisjonell undervisning. Andre undersøkelser rapporterer om lignende funn, der elever og studenter har møtt uforberedt til undervisning og uttrykt misnøye med undervisningsformen (se f.eks. Herreid \& Schiller, 2013; Lo \& Hew, 2017). Dette vil nok særlig kunne være en utfordring for elever i skolen. De fleste studiene av omvendt undervisning har tatt utgangspunkt i studenter i høyere utdanning. Det er ikke urimelig å anta at voksne studenter er mer selvgående enn elever i skolen, og i større grad har den nødvendige arbeidsdisiplinen til å se og prøve å forstå videoene. Dermed kan det tenkes at elever i skolealder oftere enn voksne studenter vil møte uforberedt til undervisning.

\section{Metode}

\section{Design}

For å undersøke de to problemstillingene ble et kvasieksperiment gjennomført på tre videregående skoler over ett år. Et kvasieksperiment har, som randomiserte eksperimenter, til hensikt å undersøke et hypotetisert forhold mellom årsak og virkning ved å se på tilstanden før og etter et bestemt tiltak (Shadish, Cook \& Campbell, 2002). Men i et kvasieksperiment allokeres ikke deltagerne vilkårlig til grupper. Det betyr at resultater av kvasieksperimenter bør tolkes med varsomhet. Likevel kan kvasieksperimenter si noe om mulige årsaksforhold gjennom statistiske kontroller, og de er passende for utforskende undersøkelser (Shadish et al., 2002).

I denne studien ble elevene delt inn i to grupper: omvendt undervisning og tradisjonell undervisning. Men de ble ikke vilkårlig tildelt omvendt undervisning eller tradisjonell undervisning, og kan derfor klassifiseres som en kvasieksperimentell undersøkelse. I kvasieksperimentelle studier oppstår det ofte seleksjonsbias, og det er grunn til å anta at elevene på de tre skolene er noe forskjellige. Elevene i begge gruppene besvarte derfor en felles før-test i starten av skoleåret. En felles før-test gjør det mulig å undersøke i hvert fall delvis retning og størrelse på seleksjonsbiasen (Shadish et al., 2002). Men til tross for en felles før-test, kan det eksistere systematiske forskjeller mellom gruppene som ikke registreres, og som kan forklare eventuelle observerte effekter ved slutten av studien. Det vil derfor være nødvendig å vurdere alternative forklaringer av en eventuell observert effekt av tiltaket.

Ved starten av skoleåret ble elevene gitt en test som dekker generell kunnskap og ferdigheter innenfor grunnskolematematikk, og et spørreskjema om oppfatninger om matematikk. I slutten av skoleåret ble elevene gitt samme 
matematikktest og spørreskjema, i tillegg til en matematikktest som dekket kompetansemålene i matematikkurset elevene hadde hatt det året. Jeg analyserte deretter besvarelsene for å se om det var statistiske forskjeller i endring av læringsutbytte og oppfatninger om matematikk mellom elever som hadde hatt omvendt undervisning og elever som hadde hatt tradisjonell undervisning.

\section{Utvalg}

Tre videregående skoler i en middels stor norsk by deltok i studien. Elevene gikk i første klasse i videregående skole og tok studiespesialiserende matematikk 1T. Den ene skolen, skole A, besluttet ett år før studien startet å innføre omvendt undervisning i matematikk. Skolen hadde derfor gjennomført ett skoleår med omvendt undervisning i matematikk da studien begynte. De to andre skolene, skole B og skole C, har tradisjonell undervisning i matematikk. Det er stor variasjon innen det som kalles tradisjonell undervisning, men som kontrast til omvendt undervisning betyr det at nytt fagstoff introduseres i fellesundervisning, og elevene gjør repetisjonsbaserte oppgaver i lekser. Innenfor disse rammene er det selvfølgelig stor variasjon, fra ferdighetsbasert undervisning der elever imiterer lærer, til mer utforskende aktiviteter der lærer går fra å være instruktør til å være veileder. Ifølge lærerne på skole $\mathrm{B}$ og skole $\mathrm{C}$ fulgte deres undervisning stort sett et mønster med at læreren først gjennomgikk nytt teoristoff, og deretter jobbet elevene individuelt med oppgaver som illustrerte den aktuelle matematiske teknikken, begrepet eller ideen. Norske undersøkelser (se f.eks. Klette, Bergem \& Roe, 2015; Bergem, Kaarstein \& Nilsen, 2016) bekrefter at dette er svært vanlige arbeidsformer i matematikkundervisningen i norsk skole.

Undervisningen ved skole A fulgte ifølge lærerne som regel en nyere forståelse av omvendt undervisning. Elevene så korte filmer før og utenfor fellesundervisning, der matematiske ideer, begreper og prosedyrer ble introdusert, og de svarte elektronisk på tilhørende oppgaver og spørsmål. Filmene er ikke lagd av lærerne selv, men av en pedagogisk leverandør ${ }^{1}$ som tilbyr en komplett læringsplattform med filmer som er tilpasset læreplan og lærebok, samt en oversikt over hvem som bruker den og hvordan den brukes. Lærerne har via læringsplattformen som ble benyttet, tilgang til oversikt over både hvem som har sett filmene og hvordan elevene hadde svart på spørsmålene og oppgavene. Dette ga lærerne en rask oversikt over hvilke temaer og typer problemstillinger som elevene slet med, og de kunne dermed tilpasse undervisningen $i$ fellesundervisningen. Fellesundervisningen besto som regel av at lærer og hele klassen først gikk gjennom og diskuterte utfordrende problemer, og deretter jobbet elevene individuelt eller i små grupper med mer tradisjonelle oppgaver i læreboka.

181 elever totalt (78 jenter og 103 gutter) deltok i studien. 84 elever fikk omvendt undervisning, mens 97 elever fikk tradisjonell undervisning. Prøver, tentamener og antall undervisningstimer var ellers tilnærmet likt på de tre skolene.

\footnotetext{
${ }^{1}$ Campus Inkrement. Se https://campus.inkrement.no/
} 


\section{Instrumenter og analyse}

Den generelle matematikktesten ble lagd i samarbeid mellom lærere ved de tre skolene og forskere i matematikkdidaktikk. Matematikktesten besto av totalt 36 oppgaver (inkludert underoppgaver), som kunne gi maksimalt 42 poeng, og den dekte et bredt kompetansebegrep slik det har blitt beskrevet tidligere i denne teksten. For å utvikle en matematikktest som dekte generell kunnskap og ferdigheter innenfor grunnskolematematikk, ble det først tatt utgangspunkt i læreplanmålene etter tiende trinn i matematikk i grunnskolen. Deretter ble TIMSS sitt rammeverk (Grønmo et al., 2013) for kognitive domener benyttet for å dekke de forskjellige kognitive prosessene som er involvert i et bredt kompetansebegrep. Rammeverket fra TIMSS er delt inn i tre domener. Det første domenet, å kunne, betyr å huske fakta, gjenkjenne objekter og uttrykk. Det andre domenet, å anvende, betyr å bruke kunnskapene og ferdighetene til å følge instrukser og løse rutineproblemer. Det tredje og siste domenet, å resonnere, er knyttet til evnen til å analysere situasjoner og sammenhenger, generalisere situasjoner, kombinere informasjon, begrunne påstander og løse problemer som ikke er rutinepregete. Det betyr at oppgavene i den generelle matematikktesten testet 1) fakta og definisjoner, 2) teknikker og algoritmer, og 3) problemløsing, argumentasjon og resonnering.

1) Skriv så enkelt som mulig: $3 y^{6}: y^{2}=$

2) Sett ring rundt det uttrykket som er størst når tallet $n$ er negativt: $\begin{array}{lllll}n-2 & n^{2} & 2 n & \frac{n}{2} & \frac{2}{n}\end{array}$

Figur 1. Eksempler fra generell matematikktest

I figur 1 er oppgave 1 et typisk eksempel på en oppgave som tester enkle algebraiske regneferdigheter, mens oppgave 2 er et eksempel på en oppgave som tester forståelse for algebraiske uttrykk.

Ved slutten av skoleåret besvarte elevene også en matematikktest som ble utformet ut fra læreplanmålene i matematikkemnet 1T. Testen besto av totalt 16 oppgaver (inkludert underoppgaver), som kunne gi maksimalt 20 poeng. Også her ble testen lagd i samarbeid mellom lærere og forskere, og den dekte et bredt kompetansebegrep i matematikk slik rammeverket fra TIMSS har definert det. Se figur 2. 


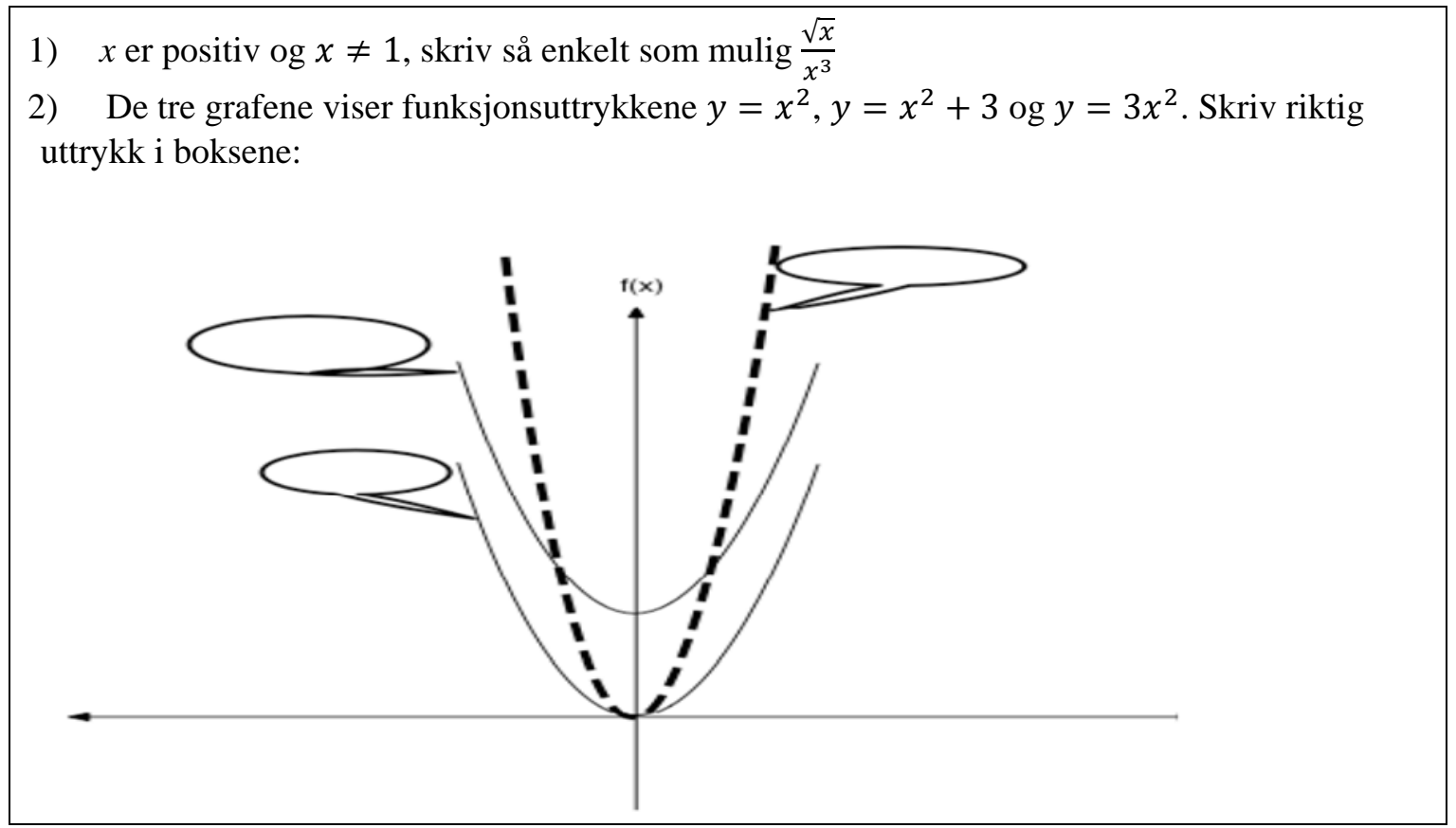

Figur 2. Eksempler fra matematikktest for $1 \mathrm{~T}$

I tillegg besvarte elevene et spørreskjema bestående av 20 spørsmål, som ble oversatt og tilpasset norske forhold ut fra to tidligere utviklede og utprøvde spørreskjemaer: Mathematics Beliefs Scales (MBS) (Fennema, Peterson, Carpenter \& Lubinski, 1990) og Mathematics Beliefs Questionnaire (MBQ) (Collier, 1972). Det var flere grunner til at nettopp disse to spørreskjemaene ble valgt som utgangspunkt. For det første er begge basert på store empiriske undersøkelser, og de har blitt benyttet og validert i en rekke senere studier. For det andre er de to spørreskjemaene direkte knyttet til begreper som jeg ønsket å måle i denne undersøkelsen. Både MBS og MBQ er utviklet for å måle elevers oppfatninger om matematikk, om læring av matematikk, og om undervisning av matematikk.

De 20 spørsmålene var delt inn i fire sammensatte mål (skalaer) og ble besvart ut fra en syvpunkts likertskala fra helt enig til helt uenig. De fire sammensatte målene var knyttet til de tre underkategoriene av oppfatninger om matematikk i skolen: oppfatninger om matematikk, oppfatninger om læring av matematikk, og oppfatninger om undervisning av matematikk. Det første sammensatte målet var indre motivasjon (eks.: Tiden går raskt når jeg jobber med matematikk), og det ble lagd for å måle interesse eller glede av matematikk, og oppfatninger om læring i matematikk. Dersom elevene opplever matematikk og matematikkundervisningen som meningsfull og tilpasset dem, vil dette muligens registreres av et mål på indre motivasjon. Det andre sammensatte målet var matematikk læeres best ved direkte instruksjon ${ }^{2}$ (eks.: Lærere bør alltid løse eksempeloppgaver før elevene skal jobbe med samme tema). Dette målet var

\footnotetext{
${ }^{2}$ Elevsvarene på det sammensatte målet matematikk læres best ved direkte instruksjon ble invertert, slik at lave verdier tyder på større enighet om at matematikk bør læres ved direkte instruksjon. Høye verdier tyder på det motsatte, nemlig at matematikk bør læres ved utforskende aktivitet.
} 
knyttet til oppfatninger om undervisning av matematikk. Omvendt undervisning kan, som sagt, frigjøre mer tid til undersøkende undervisning i fellesundervisningen. Det vil i så måte være interessant å undersøke om elevenes oppfatninger om hvordan undervisningen skal organiseres, endrer seg i løpet av skoleåret. De to siste sammensatte målene var også knyttet til mulige effekter av en slik omlegging av fellesundervisningen. Dersom elevene i større grad mottok undersøkende undervisning, kan det tenkes at elevenes oppfatninger om matematikk som fag endres. De to sammensatte målene var matematikk er en samling av fakta og regler (eks.: Matematikk er i større grad enn andre fag styrt av faste regler og prosedyrer), og matematiske problemer kan løses på mange måter (eks.: Det er ofte mange forskjellige måter å løse en matematikkoppgave på). De fire sammensatte målene er ikke et fullstendig mål på elevers oppfatninger om matematikk, men de er relevante indikatorer på viktige deler av elevers oppfatninger om matematikk. De går også grovt sett fra beregningsorienterte oppfatninger om matematikk til begrepsorienterte oppfatninger om matematikk.

Alle de fire sammensatte målene hadde akseptable verdier for intern konsistens (Cronbachs alpha); de fire sammensatte målene gikk fra 0,72 til 0,89. Elevene brukte 90 minutter ved starten av skoleåret til å besvare den generelle matematikktesten og spørreskjemaet, og de brukte 135 minutter ved slutten av skoleåret til å besvare den generelle matematikktesten, spørreskjemaet og matematikktesten for $1 \mathrm{~T}$.

Flernivåanalyser viste at enkeltobservasjonene kunne regnes som uavhengige, til tross for den hierarkiske datastrukturen. For å undersøke forskjeller i elevenes prestasjoner på testene og spørreskjemaet før og etter skoleåret, benyttet jeg dermed seks lineære regresjonsmodeller. De avhengige variablene var endring i resultat for elevene på den generelle matematikktesten og samlemålene i spørreskjemaet fra starten av skoleåret til slutten av skoleåret. I tillegg ble resultatet på matematikktesten for $1 \mathrm{~T}$ benyttet som avhengig variabel i én av de seks regresjonsmodellene. For den generelle matematikktesten og matematikktesten for $1 \mathrm{~T}$ ble resultat på den generelle matematikktesten ved starten av skoleåret benyttet som kovariat. For samlemålene i spørreskjemaet, ble resultatet på det aktuelle samlemålet ved starten av skoleåret benyttet som kovariat. Slike modeller kalles også ANCOVA, og er ifølge Dimitrov og Rumril (2003) og Dugard og Todman (1995) den anbefalte analysemetoden for «nonequivalent comparison group tests». Alle antagelser for ANCOVA var tilfredsstilt.

\section{Resultater}

Figur 3 viser resultater fra før- og etter-testen for generell matematikk og 1Ttesten, for elevene som hadde henholdsvis tradisjonell og omvendt undervisning. 


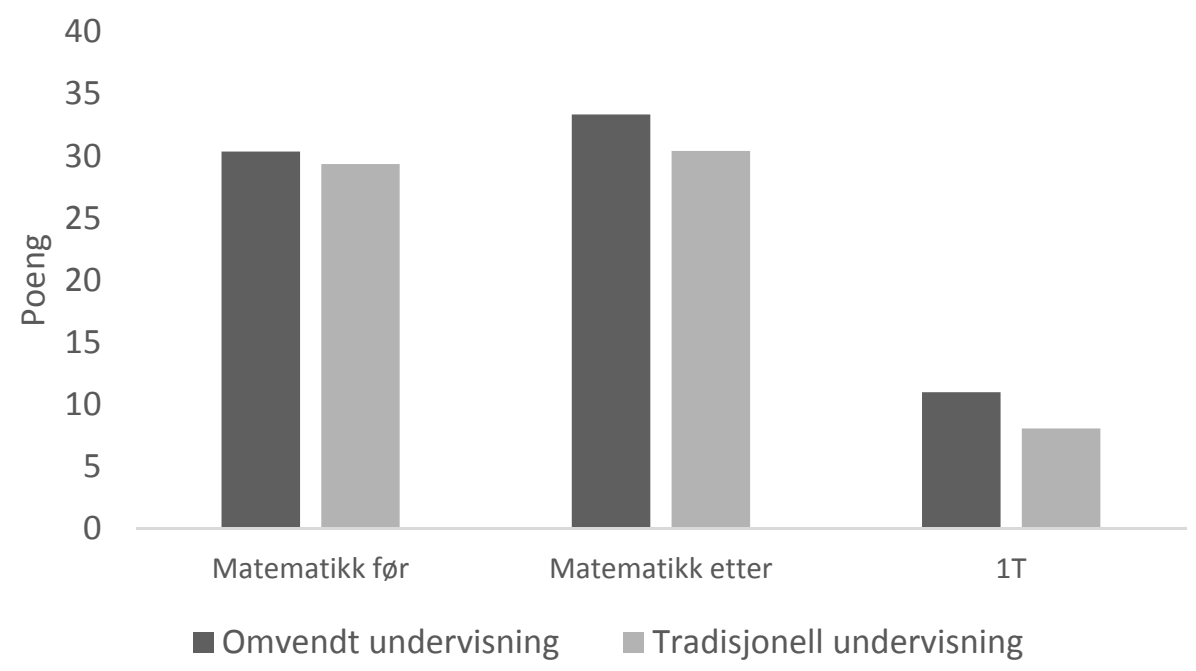

Figur 3. Søylediagram av elevenes matematikkresultater

Tabell 1 viser elevenes gjennomsnittlige skår før og etter skoleåret for den generelle matematikktesten, testen for matematikkemnet $1 \mathrm{~T}$, og de sammensatte målene indre motivasjon, matematikk er regelstyrt, direkte instruksjon og mange løsninger fra spørreskjemaet. Resultatene er delt inn etter hvilken undervisningsform elevene fikk. Skalaen for den generelle matematikktesten gikk fra 0 til 42 poeng, mens testen for $1 \mathrm{~T}$ gikk fra 0 til 20 poeng. For variablene indre motivasjon, matematikk er regelstyrt, direkte instruksjon og mange løsninger gikk skalaen fra 0 til 20 poeng.

Tabell 1. Deskriptiv statistikk for uavhengige og avhengige variabler

\begin{tabular}{llll}
\hline Mål & Før & Etter & N \\
\hline Generell matematikk & & & \\
$\quad$ Omvendt undervisning & $30,36(4,57)$ & $33,35(4,62)$ & 84 \\
$\quad$ Tradisjonell undervisning & $29,36(5,21)$ & $30,41(4,94)$ & 97 \\
1T & & & \\
$\quad$ Omvendt undervisning & - & $10,99(4,25)$ & 84 \\
$\quad$ Tradisjonell undervisning & - & $8,07(3,63)$ & 97 \\
Indre motivasjon & & & \\
$\quad$ Omvendt undervisning & $16,78(6,12)$ & $18,38(5,16)$ & 84 \\
$\quad$ Tradisjonell undervisning & $17,40(7,17)$ & $19,58(5,99)$ & 97 \\
Matematikk er regelstyrt & & & \\
$\quad$ Omvendt undervisning & $13,10(3,55)$ & $13,61(3,04)$ & 84 \\
$\quad$ Tradisjonell undervisning & $13,35(3,43)$ & $13,25(3,33)$ & 97 \\
Direkte instruksjon & & & \\
$\quad$ Omvendt undervisning & $14,05(4,09)$ & $14,80(3,84)$ & 84 \\
$\quad$ Tradisjonell undervisning & $12,67(3,56)$ & $12,89(3,74)$ & 97 \\
Mange løsninger & & & \\
$\quad$ Omvendt undervisning & $15,21(4,01)$ & $15,34(4,53)$ & 84 \\
$\quad$ Tradisjonell undervisning & $14,53(3,97)$ & $13,60(3,60)$ & 97 \\
\hline
\end{tabular}

Merk: Standardavvik i parentesene. 
For å ta hensyn til den hierarkiske strukturen i observasjonene - det vil si at elevene gikk i forskjellige klasser - ble det først gjennomført seks flernivåanalyser. Flernivåanalyser benyttes ofte når data er strukturert i hierarkier, slik som elever i klasser, uten at man bryter krav om uavhengighet (Tabachnick \& Fidell, 2014). Den avhengige variabelen i de seks modellene var henholdsvis endring fra før-test til etter-test for skår på den generelle matematikktesten og de fire sammensatte målene i spørreskjemaet, samt skår på testen for matematikkemnet 1T. For den generelle matematikktesten og matematikktesten for 1T ble matematikkskår på den generelle matematikktesten ved starten av skoleåret (førtest) benyttet som uavhengig variabel. For de sammensatte målene i spørreskjemaet ble resultatet på det aktuelle sammensatte målet ved starten av skoleåret benyttet som uavhengig variabel. I tillegg var undervisningsform og hvilken klasse eleven tilhørte benyttet som uavhengige variabler i alle modellene. Elevenes skår på testene og de sammensatte målene i spørreskjemaet var nivå én, mens klassene elevene tilhørte og undervisningsform var nivå to. Analysene ble gjennomført i tråd med anbefalinger fra Tabachnick og Fidell (2014) med tanke på utvalgsstørrelse, modellevaluering og modellantagelser (se også f.eks. Gelman \& Hill, 2006).

Flernivåanalysene for hver av de seks avhengige variablene besto først av en intercept only model for å undersøke intraklassekorrelasjonen. Intraklassekorrelasjon er et mål på hvor mye variasjon mellom gruppene utgjør av den totale variasjonen. Deretter ble en random slope modell testet for å se om stigningstallene mellom klassene var signifikant forskjellige. En flernivåanalyse er ikke nødvendig dersom det ikke er noen meningsfull gjennomsnittlig forskjell mellom gruppene i stigningstall og/eller skjæringspunkt (Tabachnick \& Fidell, 2014). Resultatene av analysene viste at det ikke var signifikante forskjeller mellom klassene, og jeg kunne derfor anta uavhengighet mellom de enkelte observasjonene og benytte en enklere lineær modell - også kalt ANCOVA. ${ }^{3}$ Analysene ble utført ved bruk av SPSS MIXED MODELS v. 25. Tabell 2 viser resultatene av de seks lineære modellene.

Seks separate analyser med lineære modeller (ANCOVA) ble gjennomført. Den avhengige variabelen var resultat ved skoleårets slutt på henholdsvis test for generell matematikkunnskap (generell matematikk), test for matematikkemnet $1 \mathrm{~T}$ (1T), og på de sammensatte målene indre motivasjon (indre motivasjon), matematikk som en samling av fakta og regler (matematikk er regelstyrt), matematikk læres best ved direkte instruksjon (direkte instruksjon), og matematiske problemer kan løses på mange måter (mange løsninger). Undervisningsform var ikke en signifikant uavhengig variabel for indre motivasjon $[F(1,180)=1,78$; $\mathrm{p}>0,05]$ og matematikk er regelstyrt $[\mathrm{F}(1,180)=1,31 ; \mathrm{p}>0,05]$. For generell matematikk $[\mathrm{F}(1,180)=17,97 ; \mathrm{p}<0,01], 1 \mathrm{~T}$ matematikk $[\mathrm{F}(1,180)=9,10 ; \mathrm{p}<0,01]$,

\footnotetext{
${ }^{3}$ Jeg gjennomførte også seks to-nivåanalyser, med klasse på nivå to, og med undervisningsform og elevens førskår på nivå én. Resultatene av disse analysene var tilsvarende analyseresultatene av de enklere modellene - dvs. ingen vesentlige forskjeller.
} 
mange løsninger $[\mathrm{F}(1,180)=7,14 ; \mathrm{p}<0,05]$ og direkte instruksjon $[\mathrm{F}(1,180)=5,05$; $\mathrm{p}<0,05]$ var undervisningsform en signifikant uavhengig variabel.

Tabell 2. Resultater for de lineære modellene

\begin{tabular}{lrrrr}
\hline Kilde & $\mathrm{B}$ & $\mathrm{SE}$ & $\mathrm{F}$ & $\mathrm{SS}$ \\
\hline Generell matematikk & & & & \\
$\quad$ Matematikk før & $-0,36$ & 0,06 & $42,25^{* *}$ & 547,66 \\
$\quad$ Undervisningsform & 2,29 & 0,54 & $17,97^{* *}$ & 232,92 \\
1T & & & & \\
$\quad$ Matematikk før & 0,31 & 0,06 & $31,55^{* *}$ & 416,38 \\
$\quad$ Undervisningsform & 1,64 & 0,54 & $9,10^{* *}$ & 120,06 \\
Indre motivasjon & & & & \\
$\quad$ Indre motivasjon før & $-0,48$ & 0,05 & $94,21^{* *}$ & 1825,14 \\
$\quad$ Undervisningsform & $-0,87$ & 0,66 & 1,78 & 34,03 \\
Matematikk er regelstyrt & & & & \\
$\quad$ Matemematikk er regelstyrt før & $-0,54$ & 0,06 & $82,11^{* *}$ & 632,99 \\
$\quad$ Undervisningsform & 0,47 & 0,41 & 1,31 & 10,07 \\
Direkte instruksjon & & & & \\
$\quad$ Direkte instruksjon før & $-0,51$ & 0,07 & $62,63^{* *}$ & 684,28 \\
$\quad$ Undervisningsform & 1,12 & 0,50 & $5,05^{*}$ & 55,12 \\
Mange løsninger & & & & \\
$\quad$ Mange løsninger før & $-0,46$ & 0,07 & $50,93^{* *}$ & 606,43 \\
$\quad$ Undervisningsform & 1,38 & 0,52 & $7,14^{*}$ & 85,00 \\
\hline Mer & & & & \\
\hline
\end{tabular}

Merk: ${ }^{* *} \mathrm{p}<0,01$, og $* \mathrm{p}<0,05$.

Undervisningsform hadde en statistisk signifikant effekt på testresutatene for generell matematikk og 1T, samt de sammensatte målene direkte instruksjon og mange løsninger. For generell matematikk ga omvendt undervisning en økning på 2,29 poeng. For $1 \mathrm{~T}$ ga omvendt undervisning en økning på 1,64 poeng. Omvendt undervisning ga en økning på 1,38 poeng for det sammensatte målet mange løsninger. For det sammensatte målet direkte instruksjon hadde omvendt undervisning en positiv effekt på 1,12 poeng.

\section{Diskusjon}

Forskningsspørsmålene i denne undersøkelsen var: a) I hvilken grad påvirker omvendt undervisning i matematikk elevenes matematikkunnskap? Og b) I hvilken grad påvirker omvendt undervisning i matematikk elevenes oppfatninger om matematikk? Analysene viste at det var signifikante forskjeller mellom gruppene i skår på begge kunnskapstestene og to av de sammensatte målene i spørreskjemaet. Elevene som fikk omvendt undervisning skåret høyere ved skoleårets slutt enn elevene som fikk tradisjonell undervisning på testen for generell matematikk, testen for $1 \mathrm{~T}$, og de sammensatte målene matematikk læres best ved direkte instruksjon og matematiske problemer kan løses på mange måter. 
Som i de to studiene Bishop og Verleger (2013) identifiserte som rendyrkede omvendt undervisningsdesign (Day \& Folay, 2006; Moravec et al., 2010), indikerte også denne studien et positivt faglig læringsutbytte for lærende som fikk omvendt undervisning. I Norge har Krumsvik og Jones (2016) rapportert om lignende funn, der de konkluderer med at det er en positiv sammenheng mellom lærerens omvendte undervisning og elevenes faglige læringsutbytte. For testen i generell matematikkunnskap ga omvendt undervisning en økning på 2,29 poeng sammenlignet med tradisjonell undervisning. Det tilsvarer ca. 5,3 \% økning på ett år. For testen i 1T-matematikk, ga omvendt undervisning en økning på 1,64 poeng sammenlignet med tradisjonell undervisning. Det tilsvarer ca. 7,8 \% økning på ett år. I utgangspunktet fremstår disse endringene som små. Men vi vet at individuelle elevers faglige fremgang vanligvis er relativt langsom; en økning per år på kun 10-15 \% eller 0,25-0,4 standardavvik på standardiserte faglige tester er vanlig (Wiliam, 2010). Denne undersøkelsen så på endringer i faglige og affektive målinger over kun ett år. I et lengre perspektiv, gitt en kumulativ effekt, kan det tenkes at omvendt undervisning kan ha en betydelig positiv læringseffekt.

Resultatene indikerer også at elevenes oppfatninger om matematikk har utviklet seg forskjellig i de to gruppene. Elevene som fikk omvendt undervisning, mente i større grad etter skoleåret at matematiske problemer kan løses på flere forskjellige måter og at matematikk bør læres ved utforskende aktivitet. Dette kan forklares med at omvendt undervisning skal kunne legge til rette for at elever aktivt konstruerer kunnskap gjennom en meningssøkende prosess der nye inntrykk forstås i lys av eksisterende kunnskap, mens de løser utfordrende problemer i matematikk. Det er her dog viktig å påpeke særlig noen forbehold. For det sammensatte målet direkte instruksjon, som er et mål på elevenes oppfatninger om undersøkende matematikk, hadde begge gruppene fremgang. Men fremgangen for elevene som fikk omvendt undervisning, var signifikant større enn for elevene som fikk tradisjonell undervisning. For det sammensatte målet mange løsninger skyldtes forskjellen mellom de to gruppene at elevene som fikk tradisjonell undervisning, skåret betydelig svakere etter skoleåret. Med andre ord ble elevene i kontrollgruppen i løpet av skoleåret mer overbevist om at matematiske problemer som regel ikke kan løses på flere forskjellige måter. Det kan tyde på at tradisjonell undervisning i matematikk i det første året i videregående skole i stor grad vektlegger fakta, teknikker og prosedyrer (Schoenfeld, 1992). Det er også nødvendig å påpeke at effektstørrelsene er relativt små. Vi kan dermed ikke si at omvendt undervisning i seg selv legger til rette for at elever blir mer positive til undersøkende undervisning. Noe som er naturlig, da dette også vil avhenge av det matematiske innholdet i undervisningen.

Et siste poeng er at bedre faglige resultater ofte i seg selv vil påvirke elevenes oppfatninger om faget (Zan, Brown, Evans \& Hannula, 2006). Det kan dermed tenkes at elevenes endring i oppfatninger om matematikk skyldes den faglige fremgangen, og ikke nødvendigvis den omvendte undervisningen. Her viser dog analysene noen tilsynelatende motstridende funn. I motsetning til mange 
løsninger og direkte instruksjon hadde omvendt undervisning ikke en signifikant effekt på endring i oppfatninger om matematikk som en samling av fakta og regler. Det kan tenkes at dette er oppfatninger som er vanskeligere å endre enn andre oppfatninger. Matematikk som felt er i stor grad mer formalisert og abstrahert enn andre skolefag (Hersh, 1997). Men denne undersøkelsen svarer ikke på hvor sterkt oppfatningene holdes. Dermed bør resultatene av analysene som gjelder oppfatning om matematikk, tolkes med en viss varsomhet.

\section{Konklusjon}

Statistiske analyser viste en positiv og statistisk signifikant sammenheng mellom omvendt undervisning i matematikk og endring i skår på tester i matematikk og sammensatte mål om oppfatninger om matematikk. Dette kan tyde på at omvendt undervisning er et tiltak som kan være med på å styrke elevenes læringsutbytte i skolematematikk. I denne studien ble selve undervisningen ikke systematisk observert over lengre tid. For å undersøke omvendt undervisning i matematikk fremover, vil det derfor være nødvendig å gå inn og observere og analysere hva som skjer i omvendt undervisning i matematikk, både i og utenfor klasserommet. Slike undersøkelser vil kunne frembringe forklaringsmodeller som kan underbygge denne studiens hovedfunn ved å forklare hvordan og hvorfor omvendt undervisning kan ha en positiv effekt på elevenes læringsutbytte.

\section{Begrensninger}

Enhver studie har begrensninger og potensielle feilkilder som truer validitet og reliabilitet. I dette eksperimentet var for eksempel elevene ikke delt vilkårlig inn i de to undervisningsformene. For å styrke studiens gyldighet ble før-tester derfor benyttet for å kunne kontrollere statistisk for faglige forskjeller mellom gruppene ved starten av skoleåret. Her viste flernivåanalyser at det ikke var signifikante forskjeller mellom klassene - hverken i startnivå eller utvikling - på faglige tester og spørreskjemaer om oppfatninger om matematikk. Observasjonene kunne derfor behandles som uavhengige enheter. Det kunne likevel tenkes at effektene skyldes at skole A generelt løfter elevene mer enn skole B og skole C ved for eksempel et bedre læringsmiljø eller bedre lærere. Men ifølge Falch, Bensnes og Strøm (2016) som undersøkte skolekvaliteten i norske videregående skoler, er de tre skolene jevngode på områder som deltagelse, fullføring og faglig læring for den enkelte skoleelev.

Det er også verdt å nevne at selve undervisningen ikke ble observert (med sporadiske unntak), og det derfor kan være mulige ukjente faktorer som også påvirket resultatene i studien. Men ut fra lærernes utsagn var det ingen åpenbare faktorer som truet studiens design. Her vil det kunne innvendes at elevene som fikk omvendt undervisning, reagerer positivt fordi de får mer oppmerksomhet og tid med lærer, og de utsettes for «noe nytt». Dette kan i seg selv føre til økt innsats 
og motivasjon og er en generell trussel mot intern validitet i alle eksperimentelle studier - særlig kvasieksperimentelle studier. Men det er verdt å påpeke at det var skole A selv som innførte og gjennomførte omvendt undervisning. Undervisningen ved skole A ble planlagt og gjennomført uavhengig av forskere. Det var ikke et eksternt iverksatt eksperiment. Det betyr ikke at elevenes fremgang ikke kan skyldes økt oppmerksomhet, men det betyr at en eventuell økt oppmerksomhet kommer som følge av undervisningsformen til skole A og ikke kvasieksperimentet i seg selv.

Andre momenter som bør nevnes, er at det er gjennomført relativt få undersøkelser om hvordan omvendt undervisning påvirker de lærendes faglige utbytte, slik at det er vanskelig å generalisere funnene på tvers av årstrinn og fag. Videre, for å styrke studiens validitet og reliabilitet, ble testene utformet i samarbeid mellom flere forskere og lærere, med utgangspunkt i læreplanen og matematikkdidaktisk forskningslitteratur. Testene ble også rettet separat av to forskjellige forskere før resultatene ble sammenlignet og eventuelle uenigheter diskutert og avklart.

\section{Om forfatteren}

Per Øystein Haavold er førsteamanuensis ved UiT Norges arktiske universitet. Hans forskningsinteresser omfatter blant annet matematisk kreativitet, matematiske bevis og undersøkende matematikkundervisning.

Institusjonstilknytning: Institutt for lærerutdanning og pedagogikk, UiT Norges arktiske universitet, Postboks 6050 Langnes, 9037 Tromsø.

E-post: per.oystein.haavold@uit.no

\section{Referanser}

Abeysekera, L. \& Dawson, P. (2015). Motivation and cognitive load in the flipped classroom: definition, rationale and a call for research. Higher Education Research \& Development, 34(1), 1-14.

APA (2015). Top 20 principles from psychology for preK-12 teaching and learning. American Psychological Association, Coalition for Psychology in Schools and Education.

Bergem, O. K., Kaarstein, H. \& Nilsen, T. (2016). Vi kan lykkes i realfag: Resultater og analyser fra TIMMS 2015. Oslo: Universitetsforlaget.

Beswick, K. (2012). Teachers' beliefs about school mathematics and mathematicians' mathematics and their relationship to practice. Educational Studies in Mathematics, 79(1), 127-147.

Bishop, J. \& Verleger, M. (2013). The Flipped Classroom: A Survey of the Research. 120th ASEE Conference \& Exposition, Atlanta.

Collier, C. P. (1972). Prospective elementary teachers' intensity and ambivalence of beliefs about mathematics and mathematics instruction. Journal for Research in Mathematics Education, 3(3), 155-163. 
Day, J. \& Foley, J. (2006). Evaluating a web lecture intervention in a human-computer interaction course. IEEE Transactions on Education, 49(4), 420-431.

Dimitrov, D. M. \& Rumrill Jr, P. D. (2003). Pretest-posttest designs and measurement of change. Work, 20(2), 159-165.

Dugard, P. \& Todman, J. (1995). Analysis of pre-test-post-test control group designs in educational research. Educational Psychology, 15(2), 181-198.

Estes, M., Ingram, R. \& Liu, J. (2014). A review of flipped classroom research, practice, and technologies. International HETL Review, 4(7), 1-8.

Falch, T., Bensnes, S. \& Strøm, B. (2016). Skolekvalitet i videregående opplæring. Utarbeidelse av skolebidragsindikatorer og mål på skolekvalitet. SØF-rapport nr. 01/16. Trondheim: Senter for Økonomisk Forskning.

Fennema, E., Peterson, P. L., Carpenter, T. P. \& Lubinski, C. A. (1990). Teachers' attributions and beliefs about girls, boys, and mathematics. Educational Studies in Mathematics, 21(1), 55-69.

Ferreri, S. P. \& O’Connor, S. K. (2013). Redesign of a large lecture course into a small-group learning course. American Journal of Pharmaceutical Education, 77(1), Article 13.

Gelman, A. \& Hill, J. (2006). Data analysis using regression and multilevel/hierarchical models. Cambridge University press.

Grønmo, L. S., Lindquist, M., Arora, A. \& Mullis, I. V. S. (2013). TIMSS 2015 mathematics framework. I I. V. S. Mullis \& M. O. Martin (red.), TIMSS 2015 Assessment Frameworks (kap. 1). Chestnut Hill, MA: Boston College.

Hersh, R. (1997). What is mathematics, really? (Vol. 18.) New York: Oxford University Press.

Herreid, C. F. \& Schiller, N. A. (2013). Case studies and the flipped classroom. Journal of College Science Teaching, 42(5), 62-66.

Hiebert, J. \& Grouws, D. A. (2007). The effects of classroom mathematics teaching on students' learning. I F. K. Lester (red.), Second handbook of research on mathematics teaching and learning (s. 371-404). NCTM. Charlotte, NC: Information Age Publishing.

Kilpatrick, J., Swafford, J. \& Findell, B. (red.) (2001). Adding it up: Helping children learn mathematics. Washington, DC: National Academy Press.

Kjærnsli, M. \& Jensen, F. (red.) (2016). Stø kurs: Norske elevers kompetanse i naturfag, matematikk og lesing i PISA 2015. Oslo: Universitetsforlaget.

Klette, K., Bergem, O. K. \& Roe, A. (red.) (2015). Teaching and Learning in Lower Secondary Schools in the Era of PISA and TIMMS. Amsterdam: Springer Publishing.

Krumsvik, R. J. \& Jones, L. Ø. (2016). Flipped classroom i naturfag - Finnes det en sammenheng mellom omvendt undervisning (flipped classroom) og elevprestasjoner i naturfag? Norsk pedagogisk tidsskrift, 100(1), 61-73.

Kunnskapsdepartementet (2016). Tett på Realfag. Nasjonal strategi for realfag i barnehagen og grunnopplceringen (2015-2019). Hentet fra: https://www.regjeringen.no/contentassets/869faa81d1d740d297776740e67e3e65/kd_realf agsstrategi.pdf

Lage, M. J., Platt, G. J. \& Treglia, M. (2000). Inverting the classroom: A gateway to creating an inclusive learning environment. The Journal of Economic Education, 31(1), 30-43.

Lo, C. K. \& Hew, K. F. (2017). A critical review of flipped classroom challenges in K-12 education: possible solutions and recommendations for future research. Research and Practice in Technology Enhanced Learning, 12(4), 1-22.

Moravec, M., Williams, A., Aguilar-Roca, N. \& O’Dowd, D. (2010). Learn before lecture: a strategy that improves learning outcomes in a large introductory biology class. CBE-Life Sciences Education, 9(4), 473-481. 
Niss, M. \& Jensen, T. H. (2002). Kompetencer og matematiklcering: Idéer og inspiration til udvikling af matematikundervisning i Danmark (Vol. 18). Undervisningsministeriet.

NOU 2015:8 (2015). Fremtidens skole. Fornyelse av fag og kompetanser. Oslo: Departementenes sikkerhets- og serviceorganisasjon, Informasjonsforvaltning.

Philipp, R. A. (2007). Mathematics teachers’ beliefs and affect. I F. K. Lester (red.), Second handbook of research on mathematics teaching and learning (s. 257-315). NCTM. Charlotte, NC: Information Age Publishing.

Piaget, J. (1967). Biologie et connaissance (Biology and knowledge). Paris: Gallimard.

Sappington, J., Kinsey, K. \& Munsayac, K. (2002). Two studies of reading compliance among college students. Teaching of Psychology, 29(4), 272-274.

Schoenfeld, A. H. (1992). Learning to think mathematically: Problem solving, metacognition, and sense making in mathematics. I D. A. Grouws (red.), Handbook of research on mathematics teaching and learning (s. 334-370). New York: Macmillan.

Schoenfeld, A. H. \& the Teaching for Robust Understanding Project (2016). An Introduction to the Teaching for Robust Understanding (TRU) Framework. Berkeley, CA: Graduate School of Education.

Shadish, W. R., Cook, T. D. \& Campbell, D. T. (2002). Experimental and quasi-experimental designs for generalized causal inference. Boston, MA: Houghton Mifflin.

Strayer, J. (2012). How learning in an inverted classroom influences cooperation, innovation and task orientation. Learning Environments Research, 15(2), 171-193.

Tabachnick, B. G. \& Fidell, L. S. (2014). Using multivariate statistics. Allyn \& Bacon / Pearson Education.

Thompson, A. G. (1992). Teachers' beliefs and conceptions: A synthesis of the research. I D. A. Grouws (red.), Handbook of research on mathematics teaching and learning (s. 127146). New York: Macmillan.

Vygotsky, Lev (1978). Mind in Society. Harvard: Harvard University Press.

Wasserman, N. H., Quint, C., Norris, S. A. \& Carr, T. (2017). Exploring flipped classroom instruction in Calculus III. International Journal of Science and Mathematics Education, 15(3), 545-568.

Wiliam, D. (2010). Standardized testing and school accountability. Educational Psychologist, 45(2), 107-122.

Zan, R., Brown, L., Evans, J. \& Hannula, M. S. (2006). Affect in mathematics education: An introduction. Educational studies in mathematics, 63(2), 113-121. 